\begin{tabular}{llllllllll}
\hline J & $\mathbf{O}$ & UI & R & I & A & L & O & F
\end{tabular}

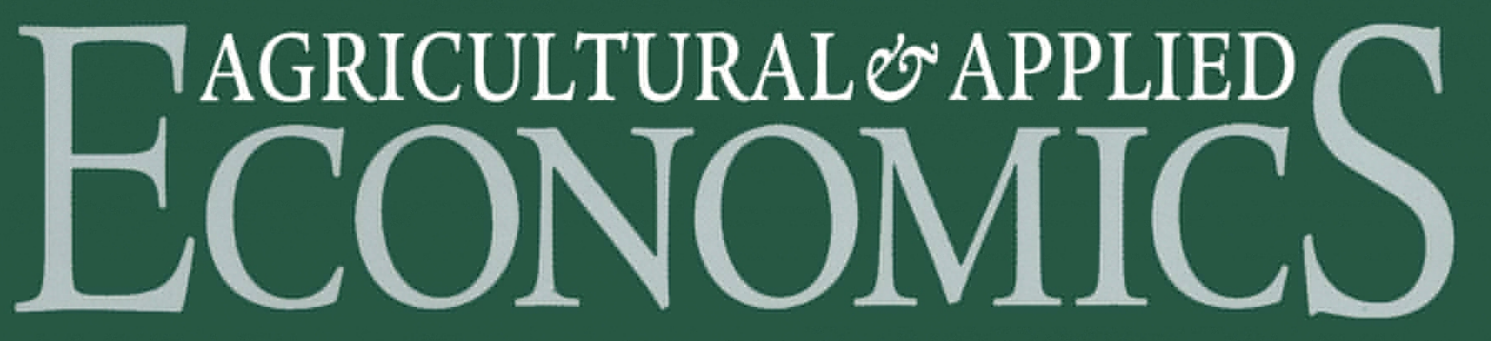

\title{
VOLLIME 44
}

\section{Proceedings from the Annual Meetings of the Southern Agricultural Economics Association held February 2012 in Birmingham, Alabama}

\section{Presidential Address}

Regional Views on the Role of Immigrant Labor on U.S. and Southern Dairies / C. Parr Rosaon

\section{Lifetime Achievement Awards}

Market Failures and Land Grant Universities / Francis M. Epplin

Thoughts on Interntional Students / Henry W. Kinmucan

Some Thoughts on Climate Change as an Agrieultural Economic Issue / Bruce A. McCarl

\section{Invited Paper Sessions}

The "A" in SAEA - Agricultural... or Applied? / Hal Harris

Why "Applied" Should be Included in the Name of Our Professional Association / John E. Lee, Jr.

The Economic Impacts of Self-Employment / Stephan J. Goetz David A. Fleming, and Anil Rupasingha

Willingness to Pay for Broadband Aceess by Kentucky Farmers / Chris Jeffcoat, Alison F. Davis, and Woyang $H u$

Discussion: Economic Opportunities in Rural Communities / J. Matthew Fannin

Historical Performance of Commodity and Stock Markets / Hector O. Zapata, Joshua D. Detre, and Tatsuya Hanabuchi

Performance of Publicly Traded Agricultural Companies Since 2000: Construction of the AgIndex / Gany Sohnitkey and Clayton Kramer

Financialization and Structural Change in Commodity Futures Markets / Scott H. Irwin and Dwight R. Sanders

Discussion: Agricultural Commodities and Agribusiness Stocks as Financial Assets / B. Wade Brarsen

Disentangling Com Price Volutility: The Role of Global Demand, Speculation, and Energy / Lihong Lu McPhail, Xaodong Du, and Andrew Mahammad

Evaluating the Causes of Rising Food Prices in Low and Middle Income Countries / Osei Yeboah.

Saleen Shatk, and Obed Quaicoe

Discussion: Causes of Agricultural and Food Price Inflation and Volatility / Norbert Wilson

Abstracts

Selected Papers, Posters, and Organtized Symposia, SAEA 2012 Annual Meetings

\section{SAEA Business}

Editors' Report / Mary A, Marchant and Darrell J, Bosch

Membership Report/John.J. VanSickle

Treasurer's Report / Jeffrey L Jardan 


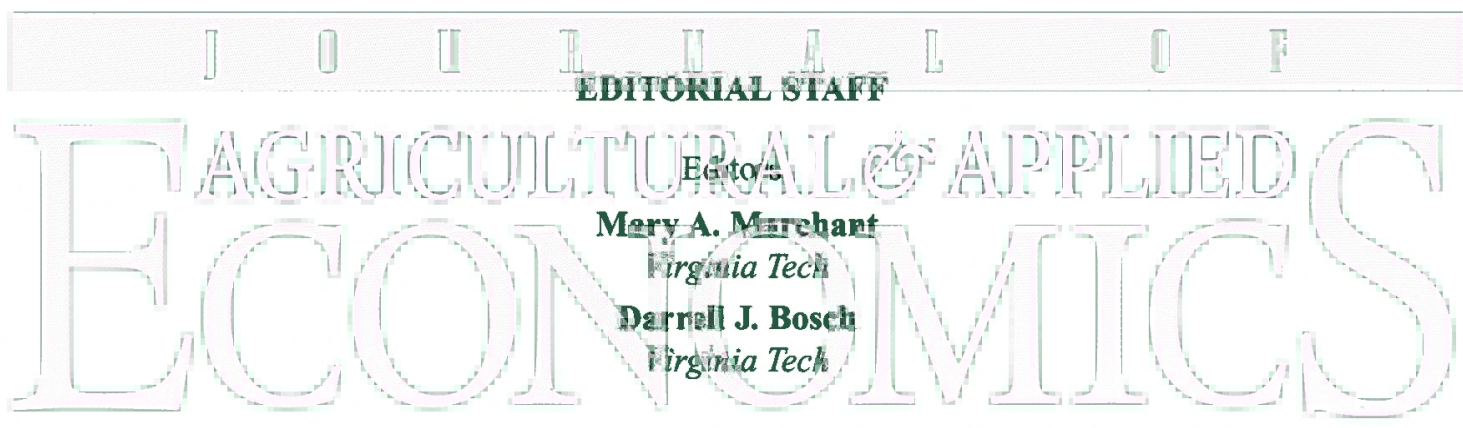

Associate Editor

Michgel Wetzstein

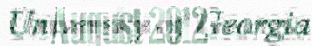

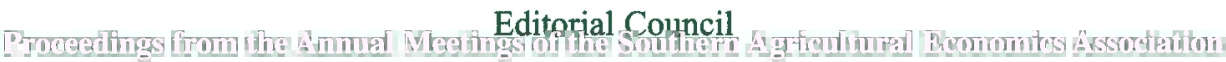

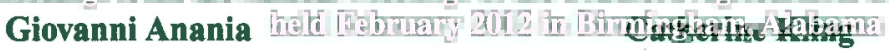

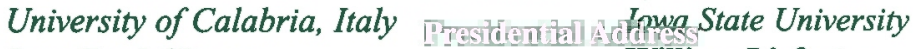

Jean Paul Chavas

William Liefert

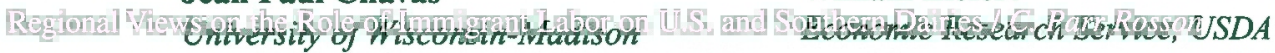

Keith Coble

Mississippi State University

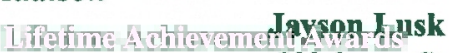

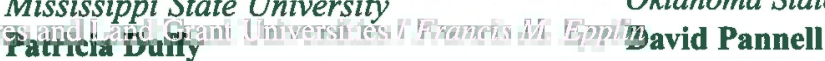

Thow

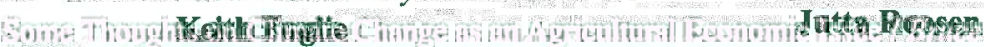

Economic Research Service, USDA Technische Universitaet Muenchen

Barry K. Goodwin

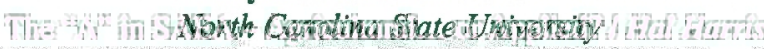

D. Whs Harrisin:

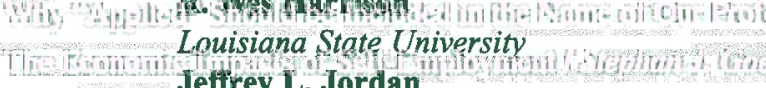

Louisiana State University
Jeffrey L. Jordan

Kansas State University

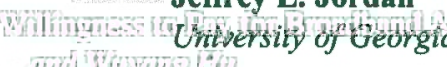

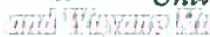

Mawn Thilmany MeFayden

Colorado State University

Sophie Thoyer

Montpeitier Supagro, France

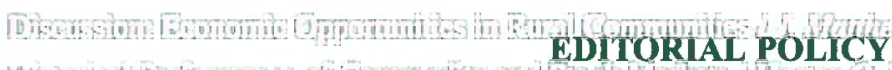

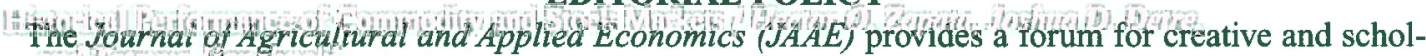
arly work in agricultural economics and related areas. Contributions on methodology and applica-

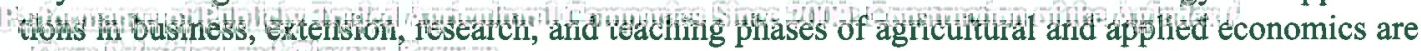
equally encouraged. Stubmitted manuscripts are subject to peer review for publication consideration.

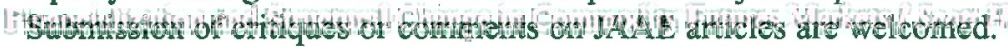

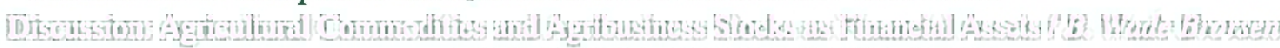

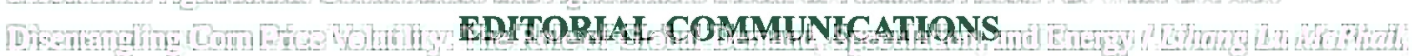

Please address edicorial cortrespondence to one of the following co-editors: Darrell Bosch,

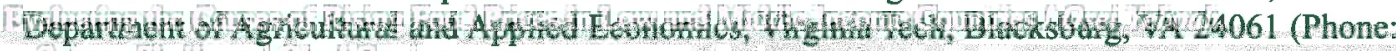

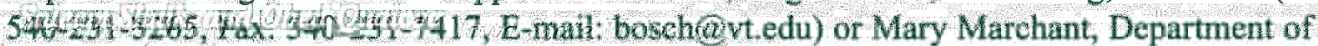

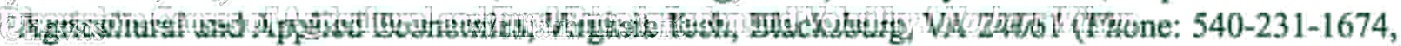

Fax: 540-231-7417, E-mail: mary marchantevkapdo Maruscripts should be submitted on-line fol-

lowing the instructions given on the inside back cover of this volume.

The Journal of Agricultural and Applied Economics (ISSN 1074-0708) is published in

February, May, August, and November by thic touthern Agricultural Economics Association if

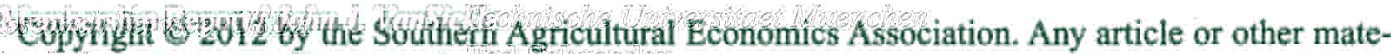

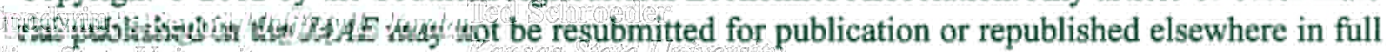

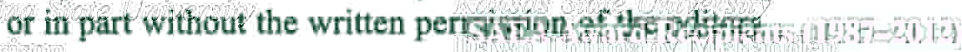




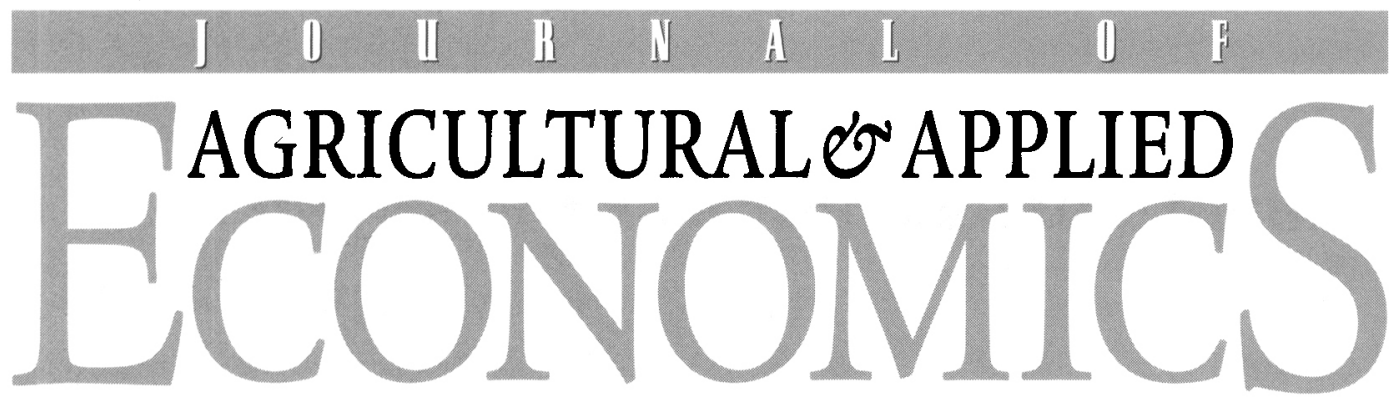

VOLLIME 44

AllitlST 2012

NUMBER 3

\section{Presidential Address}

C. Parr Rosson . . . . . . . . . . . . . . . . . . . . . . . . . 267

Regional Views on the Role of Immigrant Labor on U.S. and Southern Dairies /

C. Parr Rosson. . . . . . . . . . . . . . . . . . . . . . . . . . . . . . 269

\section{Lifetime Achievement Awards}

Francis M. Epplin . . . . . . . . . . . . . . . . . . . . . . . . . . . . 279

Market Failures and Land Grant Universities / Francis M. Epplin. . . . . . . . . . . . 281

Henry W. Kinnucan . . . . . . . . . . . . . . . . . . . . . . . . . 291

Thoughts on International Students / Henry W. Kinnucan . . . . . . . . . . . . . . . . 293

Bruce A. McCarl . . . . . . . . . . . . . . . . . . . . . . . . . . . . . . . 297

Some Thoughts on Climate Change as an Agricultural Economic Issue / Bruce A. McCarl . . . 299

\section{Invited Paper Sessions}

\section{Session Title: A Debate: The 'A' in SAEA: Is it Applied or Agricultural?}

The "A" in SAEA - Agricultural . . or Applied? / Hal Harris . . . . . . . . . . . . . . . 307

Why "Applied" Should be Included in the Name of Our Professional Association /

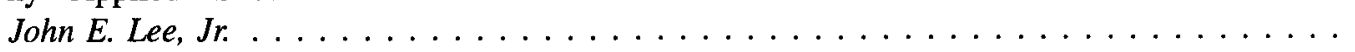

\section{Session Title: Economic Opportunities in Rural Communities}

The Economic Impacts of Self-Employment / Stephan J. Goetz, David A. Fleming, and Anil Rupasingha . . . . . . . . . . . . . . . . . . . . . . . . . . . 315

Willingness to Pay for Broadband Access by Kentucky Farmers / Chris Jeffcoat, Alison F. Davis,

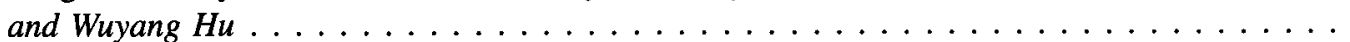

Discussion: Economic Opportunities in Rural Communities / J. Matthew Fannin . . . . . . . .

\section{Session Title: Agricultural Commodities and Agribusiness Stocks as Financial Assets}

Historical Performance of Commodity and Stock Markets / Hector O. Zapata, Joshua D. Detre,

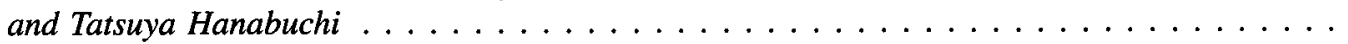


Performance of Publicly Traded Agricultural Companies Since 2000: Construction of the AgIndex / Gary Schnitkey and Clayton Kramer . . . . . . . . . . . . . . . . . . 359

Financialization and Structural Change in Commodity Futures Markets / Scott H. Irwin

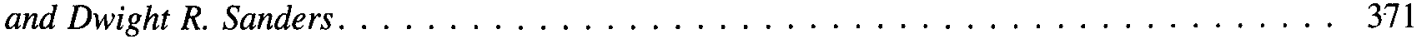

Discussion: Agricultural Commodities and Agribusiness Stocks as Financial Assets / B. Wade Brorsen . . . . . . . . . . . . . . . . . . . . . . . . . . . . . . . . . . . . 397

\section{Session Title: Causes of Agricultural and Food Price Inflation and Volatility}

Disentangling Corn Price Volatility: The Role of Global Demand, Speculation, and Energy / Lihong Lu McPhail, Xiaodong Du, and Andrew Muhammad

Evaluating the Causes of Rising Food Prices in Low and Middle Income Countries / Osei Yeboah, Saleem Shaik, and Obed Quaicoe . . . . . . . . . . . . . . . . 411

Discussion: Causes of Agricultural and Food Price Inflation and Volatility / Norbert Wilson . . 423

\section{Abstracts}

Selected Papers, Posters, and Organized Symposia, SAEA 2012 Annual Meetings

\section{SAEA Business}

Editors' Report-February 5, 2012 / Mary A. Marchant and Darrell J. Bosch . . . . . . . . . . 429

Membership Report-February 5, 2012 / John J. VanSickle . . . . . . . . . . . . . . . . . 435

Treasurer's Report-February 6, 2012 / Jeffrey L. Jordan. . . . . . . . . . . . . . . . . . . . . 437

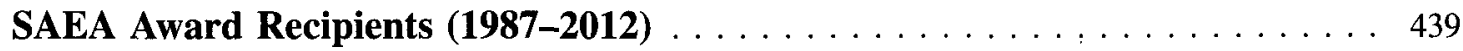

